\section{Vasa praevia - Ein seltenes Ereignis mit weitreichenden Konsequenzen: ein Fallbericht mit Literaturreport}

\section{Der Fall}

\section{$\nabla$}

Eine 19-jährige I gr 0 p wurde in der 29. + 4. SSW zur abklärenden Diagnostik und stationären Überwachung in die Klinik eingewiesen. Grund dieser Maßnahme waren seit mehreren Wochen bestehende und in der Intensität zunehmende Schmerzen im mittleren Unterbauch.

Anamnestisch gab die Schwangere einen bis dahin unauffälligen Schwangerschaftsverlauf an. Die Unterbauchschmerzen traten bewegungsunabhängig in ruhender Position auf. Zusätzlich wurde ein Druckgefühl „nach unten” in der inneren Genitalgegend beschrieben. Blutungen oder vaginaler Fluor waren nicht vorhanden.

Bei der allgemeinen klinischen Untersuchung ergaben sich zunächst keine besonderen Auffälligkeiten. Körperlicher Allgemeinzustand und orientierender Allgemeinstatus waren unauffällig. Die äußere Inspektion zeigte einen der Gestationswoche größengerechten Fundusstand. Eine erste orientierende transabdominale Sonografie zeigte eine zeitgerecht und unauffällige Biometrie und Morphologie eines in I. SL liegenden Feten. Die Fruchtwassermenge lag im Normalbereich. Im Bereich des Fundus und der kranialen Uterusvorderwand stellte sich eine unauffällige Plazenta (Grannum I) ohne Anhalt für Lösungszeichen dar. Der Zervikalbereich war transabdominal zunächst nicht einsehbar.

Anschließend erfolgten standardgemäß die vaginalen Untersuchungsverfahren: Eine Spekulumeinstellung zeigte einen unauffälligen Vaginalbefund. Die Portio war erhalten. Der äußere Muttermund in der Spiegeleinstellung geschlossen. Der Vaginal-pH war mit 4,0 im physiologischen Bereich. Es erfolgten zusätzlich Abstriche aus dem Zervikalkanal und dem hinteren Scheidengewölbe zur mikrobiologischen Untersuchung.

In der Vaginalsonografie zeigte sich ein unauffälliger Zervikalbereich. Die Zervixlänge betrug $38 \mathrm{~mm}$ ohne Anzeichen einer inneren Trichterbildung. Ebenfalls diagnostiziert wurde ein zwischen

\section{Vasa Previa - a Case Report and Review of the Literature}

\author{
Case Report \\ $\nabla$
}

A 19-year old woman, prima gravida, nullipara in the $29^{\text {th }}+4$ week of pregnancy, was admitted to the clinic for clarification and diagnosis. The reason for her admission was, for several weeks, persistent and increasing pain in the middle of the lower abdomen.

During the anamnesis, the patient reported up to the first occurrence of symptoms an event free course of the pregnancy. The lower abdominal pain occurred independent from movement in the resting position. In addition, the patient reported a "downward" pressure in the genital region. Neither bleeding nor vaginal discharge were reported.

During the general medical examination nothing special was observed. Physical and mental status were inconspicuous. The external examination showed the fundus in compliance with the gestational time. In the first trans-abdominal ultrasound the fetus was observed in I. SL position and biometrically and morphologically within the gestational time. The amount of amniotic fluid was within the normal range. The placenta was normal and without any signs of detachment in the areas of the fundus and the cranial front of the uterus (Grannum I). The cervical area was not visible transabdominally.

Standard vaginal examinations followed and were the following: in the spekulum inspection the vagina was unsuspicious; the portio was intact; the exterior cervical os of the uterus still closed; vaginal $\mathrm{pH}$ was 4.0 and within the physiological range; smears were taken from the cervix and the posterior vaginal wall for microbiological tests.

In the vaginal ultrasound, the cervical area was normal. The length of the cervix was $38 \mathrm{~mm}$ without any signs of internal infundibulum. A vessel was located between the fetal cranium and the internal cervix and showed blood circulation in the colour doppler. The patient reported that 2 weeks ago her obstetrician had reported the umbilical cord to be "in front of the fetal cranium". Ultrasound evaluation was in congruence with umbilical vessels. The patient was admitted to the ward for monitoring. Cardiotocogrammes were all within normal range. Blood tests did neither reveal any signs of an acute inflammation.

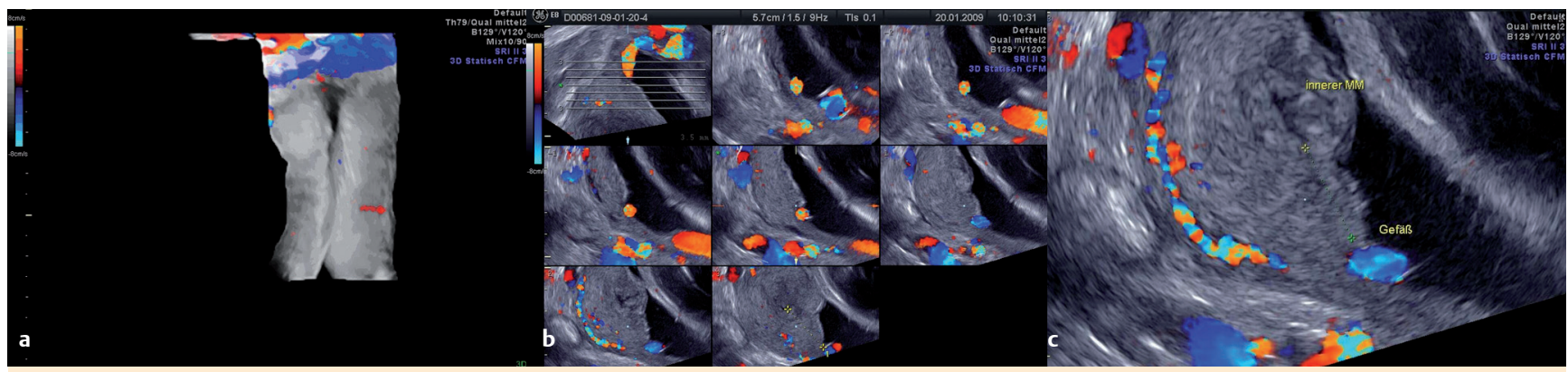

Abb. 1 Der Sagittalschnitt der Vaginalsonografie lässt Gefäßstränge vermuten, welche direkt vor dem inneren Muttermund liegen a. Die TUI-Schichtung (Tomographic Ultrasound Imaging) ermöglicht eine genauere Lokalisierung b. Erst durch Herausarbeiten der Transversalebene wird sichtbar, dass die Gefäße in einem Abstand von ca. $1,5 \mathrm{~cm}$ vom zentralen Teil des inneren Muttermunds liegen c.

Fig. 1 Sagittal Plane in transvaginal sonography shows vessels in direct proximity to the inner cervical os a. Tomographic Ultrasound Imaging (TUI) allows exact localisation of the vessels $\mathbf{b}$. Rotation of the Transversal plane shows a distance of $1.5 \mathrm{~cm}$ between inner cervical os and Vasa praevia $\mathbf{c}$. 
dem fetalen Schädel und dem inneren Muttermund liegender Gefäßstrang, der im Farbdoppler eine Blutzirkulation anzeigte. Auf Nachfrage teilte die Patientin mit, dass beim niedergelassenen Facharzt bereits 2 Wochen zuvor die „Nabelschnur vor dem Köpfchen gelegen hätte”. Die sonografische Darstellung ähnelte zunächst der Kaliberweite von Nabelschnurgefäßen.

Es erfolgte die stationäre Aufnahme zur Überwachung. Kardiotokogramme waren sämtlich im Normbereich. Serologisch konnten ebenfalls keine Veränderungen im Sinne einer akuten Entzündungsreaktion etc. nachgewiesen werden.

Während der folgenden 2 Tage kam es zu einem Sistieren der Beschwerden. Neben einer Anti-Thrombose-Prophylaxe mit niedermolekularem Heparin wurden der Patientin keine weiteren therapeutischen Maßnahmen verordnet.

Bei der Abschlussuntersuchung wurde eine erneute Vaginalsonografie durchgeführt. Es zeigte sich ein unveränderter Zervikalbefund. Auch der Gefäßstrang war unverändert im Vergleich zu den Voraufnahmen lokalisiert bzw. positioniert, sodass die Diagnose Vasa praevia bzw. Insertio velamentosa ( $\triangle \mathbf{A b b}$. 1a-c) gestellt wurde.

Im weiteren Verlauf wurde die Patientin engmaschig überwacht. In den durchgeführten sonografischen Untersuchungen zeigten sich weiterhin keine Veränderungen dieses Befunds. Die Patientin klagte weiter über gelegentliche Schmerzereignisse, die sich wie bereits zuvor bei längerem Stehen verstärkten.

In der 35 + 0 SSW wurde elektiv eine primäre Sectio nach MisgavLadach durchgeführt. Da es nach der Uterotomie und Entwicklung des Kindes zu einer sehr schnellen und spontanen vollständigen Lösung der Plazenta und Eihäute kam, konnte die intrauterine Inspektion und Dokumentation der aberrienden Gefäße nicht mehr erfolgen. Der weitere intra- und postoperative Verlauf gestaltete sich komplikationslos. Sie wurde von einem lebensfrischen Neugeborenen entbunden.

Die abschließende makroskopische Beurteilung der Plazenta und Eihäute bestätigte den sonografischen Befund der Vasa praevia (๑Abb. 2). Diese verliefen mit einem Durchmesser von ca. $10 \mathrm{~mm}$ frei über weite Teile der inneren Eihäute und lagen in situ knapp vor dem inneren Muttermund. Die Inspektion der Plazenta ergab keine Anomalien hinsichtlich Größe, Struktur etc. Der postoperative Verlauf gestaltete sich unauffällig, sodass die Patientin in gutem Allgemeinzustand und beschwerdefrei in die ambulante Betreuung entlassen werden konnte.

\section{Vergleich zur internationalen Literatur \\ $\nabla$}

Um den hier beschriebenen eigenen Casus mit anderen Publikationen vergleichen zu können, wurde eine systematische Literaturrecherche durchgeführt. Dabei wurden in den gängigen medizinischen Datenbanken Medline und Embase der Term „Vasa praevia AND/OR Insertio velamentosa” als Suchstrategie im Dezember 2008 definiert. Identifiziert werden konnten insgesamt 45 Publikationen, die einen thematischen Bezug zum dargestellten Casus hatten. Hier handelte es sich vorwiegend um andere Fallberichte, Fallserien oder Zusammenfassungen von Fallberichten aus englischsprachigen Journalen, die bereits seit 1949 publiziert wurden. Systematische Untersuchungen zur Diagnostik konnten nicht recherchiert werden. Alle identifizierten Publikationen wurden im Folgenden gesichtet.

In der Literatur wird die Prävalenz von Vasa praevia bzw. Insertio velamentosa zwischen 1:5000 (Heckel S et al. J Gynecol Obstet Biol Reprod 1993; 22: 184-190) bis $1: 100$ (Baulies S et al. Prenat

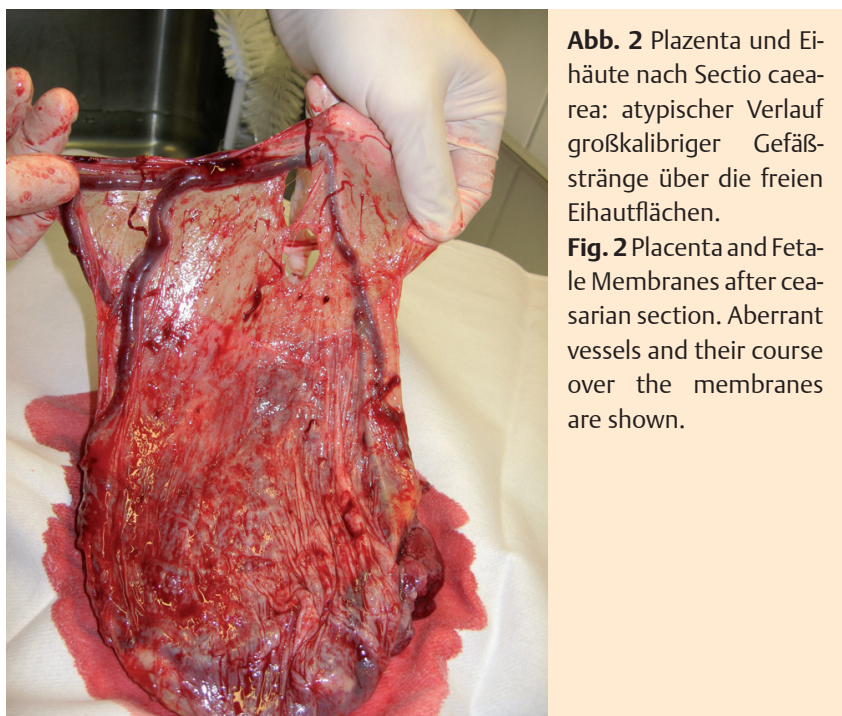

Within the following two days the complaints subsided. Besides antithrombotic prophylaxis with low-molecular heparin no further therapies were prescribed. At the final examination another vaginal ultrasound evaluation was performed. The cervix was unchanged. The vessel cord was unchanged in location and/ or position as compared to the earlier findings and the diagnosis of Vasa praevia or Insertio velamentosa ( $\bullet$ Fig. 1a-c) was assigned.

The patient was monitored closely. In the following ultrasound evaluations no changes were noticed as compared to the earlier results. The Patient complained about occasional pains which aggravated, as reported before, in prolonged upright position.

An elective primary Misgav-Ladach sectio was performed in the $35+0$ week of pregnancy. Following the uterotomy and delivery of the fetus an extreme fast and spontaneous complete detachment of the placenta and the amniotic sac occurred which made it impossible to inspect and document the aberrant vessels. The intra- and postoperative course was free of complications. The patient delivered a lively newborn. The following macroscopic evaluation of the placenta and the amniotic sac confirmed the sonographic findings of vasa praevia (OFig. 2). These ran with a diameter of approx. $10 \mathrm{~mm}$ liberally over a large part of the internal amniotic sac and in situ in front of the internal cervix. Inspection of the placenta did not reveal any anomalies concerning size and structure.

The postoperative course was normal and the patient was discharged in good condition and without complaints into the care of her obstetrician.

\section{Comparison with International Literature \\ $\nabla$}

To enable us to compare our case with other publications, a systematic literature search was performed. In December of 2008 the medical databanks Medline and Embase were searched for "Vasa praevia AND/OR Insertio velamentosa". In total 45 publications were identified via their thematic similarity to the reported case.

These were mainly other case reports, series of cases or summaries of case reports from English language journals and were published since 1949. Systematic diagnostic examinations could not be researched. All identified publications were evaluated as follows. 
Diagn 2007; 27: 595-599) in unterschiedlichen Kollektiven beschrieben. Die perinatale Letalität wird jedoch bei fehlender Diagnostik und bei Ruptur der aberierenden Gefäße dafür mit ca. $70-100 \%$ als relativ hoch beschrieben (Young M et al. Reprod Fertil Dev 1991; 3: 439-445).

Vasa praevia treten dabei in den meisten beschriebenen Fällen ohne fassbare Klinik bzw. Symptomatik auf. Nach Durchsicht und Vergleich mit der anderen Literatur ist der von uns beschriebene Fall unseres Wissens der einzig publizierte, bei der die Patientin durch eine Schmerzsymptomatik klinisch auffällig wurde. Eine vaginale Blutung bei (bekannten Vasa praevia) als weiteres maternales Symptom im klassischen Sinne ist als Zeichen einer möglichen Ruptur und damit als perinataler Notfall zu werten. Fetale Auffälligkeiten und Gefahrenzustände sind ebenfalls eher nach Ruptur von Gefäßen, eventuell in Kombination mit vaginalen Blutungen, z. B. durch kardiotkokografische Veränderungen nachweisbar (Kruitwagen RF et al. Eur J Obstet Gynecol Reprod Biol 1991; 39: 147-150).

Baulies et al. (Prenat Diagn 2007; 27: 595-599) haben in einem Kollektiv von 12063 Schwangeren insgesamt 9 Fälle mit Vasa praevia diagnostiziert und in einer Multivariatanalyse mögliche Ursachen bzw. Nebenbefunde analysiert und diskutiert. Neben einer Häufung nach IVF-Graviditäten waren präpartal bei den Betroffenen auch vermehrt Plazentaanomalien diagnostiziert worden (Plazenta bilobularis, partitia oder previa). Zu ähnlichen Befunden gelangen auch Al-Khaduri et al. (Reprod Biomed Online 2007; 14: 372-374), welche die gehäufte Entstehung von Vasa praevia nach IVF mit einer atypisch lokalisierten Implantation der Blastozyste nach künstlichem Embryotransfer begründen.

Da Vasa praevia v. a. ab dem zweiten Trimenon diagnostizierbar und klinisch relevant sind, kommt hier der frühzeitigen diagnostischen Sicherung eine entscheidende Bedeutung zu, um die dramatischen Folgen einer möglichen Ruptur zu vermeiden. Diskutiert werden in der Literatur verschiedene Verfahren. Während die digital-vaginale Tastuntersuchung sowie die Amnioskopie noch Anfang der 90er-Jahre favorisiert wurden (Cingotti M et al. Rev Fr Gynecol Obstet 1992; 87: 87-89), fanden Verfahren wie endozervikale Endoskopie (Young $\mathrm{M}$ et al. Reprod Fertil Dev 1991; 3: 439-445) oder der labortechnische Nachweis fetalen Hämoglobins nach vaginalen Blutungen (Heckel S et al. J Gynecol Obstet Biol Reprod 1993; 22: 184-190) kaum Einzug in die klinische Praxis und behielten eher experimentellen Charakter. Heute stellt die Vaginalsonografie in Kombination mit Dopplerdarstellung das diagnostische Verfahren der Wahl dar (Seince N et al. J Clin Ultrasound 2002; 30: 450-454).
In the literature, the prevalence of Vasa praevia or Insertio velamentosa is reported to be between 1:5000 (Heckel S. et al. J Gynecol Obstet Biol Reprod 1993; 22: 184-190) and 1:100 (Baulies S et al. Prenat Diagn 2007; 27: 595-599) and reported in different summaries. Prenatal mortality in case of undiagnosed cases or rupture of the aberrant vessels is relatively high with 70-100\% (Young M et al. Reprod Fertil Dev. 1991; 3: 439-445).

Vasa praevia, in most of the reported cases, occur without clearly described clinical symptomatology. After search and comparison with literature we conclude that our reported case is the only published one in which the patient was clinically symptomatic with pain. Vaginal bleeding in known Vasa praevia points as a maternal symptom to a possible rupture and therefore, should be considered a perinatale emergency. Fetal symptoms and dangerous conditions are more likely to be noticed following rupture of the vessels and in combination with vaginal bleeding, for example via cardiotocographic changes (Kruitwagen RF et al. Eur J Obstet Gynecol Reprod Biol 1991; 39: 147-150).

Baulies et al. (Prenat Diagn 2007; 27: 595-599) diagnosed in total 9 cases of Vasa praevia out of 12063 evaluated pregnant women and analyzed and discussed in a multivariability analysis possible causes and secondary findings. An accumulation of cases was identified in IVF-pregnancies and prepartal in cases where placental abnormalities were diagnosed (placenta bilobularis, partitia or previa). Similar cases were reported by Al-Khaduri et al. (Reprod Biomed Online 2007; 14: 372-374), who reasoned the increased occurrence of Vasa praevia following IVF with an atypically localized implantation of the blastocyste following artificial embryotransfer.

Since Vasa praevia can be diagnosed and become clinically relevant from the second trimester on, the early diagnosis is of importance to avoid the dramatic consequences of a possible rupture. In the literature different procedures are discussed. The digital-vaginal as well as the aminioscopic examinations were at the beginning of the 90's the preferred procedure (Cingotti M et al. Rev Fr Gynecol Obstet 1992; 87: 87-89), but others like endocervical endoscopy (Young M et al. Reprod Fertil Dev 1991; 3 : 439-445) or the laboratory proof of fetal hemoglobins following vaginal bleeding (Heckel S et al. J Gynecol Obstet Biol Reprod 1993; 22: 184-190) were not adopted in clinical praxis and kept their experimental character. Today, vaginal ultrasound in combination with doppler imaging have became the preferred diagnostic procedure (Seince N et al. J Clin Ultrasound 2002; 30: 450454). 


\section{Fazit und Empfehlungen für die Praxis}

Die häufig öffentlich diskutierte Notwendigkeit des Einsatzes einer Vaginalsonografie bei der Schwangerenbetreuung bzw. Pränataldiagnostik wird am Beispiel der Vasa praevia besonders deutlich. Bei seltenem Vorkommen führen nicht diagnostizierte Vasa praevia mit einer extrem hohen fetalen Letalität zu einem dramatischen Verlauf. In der Literatur wird kein Fall beschrieben, der nach gesicherter Diagnose zu einer fetalen oder maternalen Komplikation geführt hätte. Somit zählen Vasa praevia zu den unverzichtbaren Indikationen der kombinierten Vaginal- und Doppler-Sonografie bei der Diagnostik von Gefäßanomalien im kleinen Becken (Kirkinen P et al. Ultraschall in Med 2007; 28: 212 -215; Deckner C et al. Ultraschall in Med 2004; 25: 141-143).

Daher sollte jeder Schwangeren im zweiten Trimenon auch bei unauffälligem Schwangerschaftsverlauf und vaginalem Tastbefund eine vaginalsonografische Untersuchung angeboten werden. Bei Darstellung bzw. V. a. mögliche Gefäße im Bereich des inneren Muttermunds muss mit dem Dopplermodus ein Blutfluss ausgeschlossen werden. Die Bildgebung sollte für Verlaufskontrollen dokumentiert werden, da sich die Lokalisation von Vasa praevia im weiteren zeitlichen Verlauf kaum ändert (im Gegensatz zu differenzialdiagnostisch vorliegenden Nabelschnurgefäßen) und somit über einen Vergleich mit den Voraufnahmen die Diagnose bestätigt werden kann und muss. Eine abdominalsonografische Darstellung von Plazentaanomalien (Plazenta bilobaris, praevia etc.) muss immer eine vaginalsonografische Untersuchung zum Ausschluss von Vasa praevia nach sich ziehen. Auch zu Dokumentationszwecken sollte in diesem Fall abdominalsonografisch die Insertionsstelle der Nabelschnur an der Plazenta erfolgen. Aufgrund der Häufung nach IVF ist in diesem Fall einer Schwangeren unbedingt zu vaginalsonografischen Kontrolluntersuchungen zu raten. Eine primäre elektive Sectio sollte frühzeitig besprochen und aus Vorsicht vor Einsetzen von beginnender Wehentätigkeit und der damit verbundenen Rupturgefahr ab der $35+0$ SSW angestrebt werden.

\author{
A. Wöckel ${ }^{*}$ D. Varga*, G. Sauer, Ulm \\ *beide Autoren haben zu gleichen Anteilen an der Arbeit mitge- \\ wirkt
}

E-Mail: achim.woeckel@uniklinik-ulm.de

\section{Summary and Recommendations for Clinical Practice $\nabla$}

The frequently and openly discussed necessity to use vaginal ultrasound in the follow-up of pregnant women or in prenatal diagnostics becomes especially evident in the example of the Vasa praevia. In rare incidences, the undiagnosed Vasa praevia leads with an extremly high fetal mortality rate to a dramatic course of event. No case has been reported in the literature which, following confirmed diagnosis, has lead to fetal or maternal complications. Therefore, Vasa praevia accounts for one of the unforegoing indications in the combined vaginal- and doppler sonography in the diagnosis of vessel anomalies in the small pelvis (Kirkinen P et al. Ultraschall in Med 2007; 28: 212-215; Deckner C et al. Ultraschall in Med 2004; 25: 141-143).

Therefore, it is recommended to offer every pregnant woman in her second trimester, even if pregnancy and vaginal examination are uneventful, a vaginal sonographic examination. In case of the presentation or suspected vessels in the area of the internal cervix, blood circulation should be excluded via doppler examination. The obtained image should be documented for follow-up examinations, since the location of Vasa praevia does not change over time (as compared to differential diagnostic umbilical vessels), and therefore the diagnosis can be and has to be confirmed through comparison with earlier images. The abdominal ultrasound imaging of placental abnormalities (placenta bilobaris, praevia etc.) has to be followed by a vaginal ultrasound examination to exclude Vasa praevia. In addition, for documentation purposes, in these cases, the abdominal ultrasound imaging of the location of the umbilical cord insertion into the placenta should be performed. Due to an increased incidence following IVF, vaginal ultrasound control examinations should be suggested to every pregnant woman. The primary elective section should be discussed early on and should be aimed for from the $35^{\text {th }}+0$ week of pregnancy to prevent the danger of rupture with the commence of contractions.
A. Wöckel*, D. Varga*, G. Sauer, Ulm
* both authors equally participated in the publication
E-Mail: achim.woeckel@uniklinik-ulm.de 